\title{
Offset between GPS collar-recorded temperature in moose and ambient weather station data
}

\author{
Göran Ericsson ${ }^{1}$ (D) $\cdot$ Holger Dettki ${ }^{1} \cdot$ Wiebke Neumann $^{1} \cdot$ Jon M. Arnemo ${ }^{1,2}$. \\ Navinder J. Singh ${ }^{1}$
}

Received: 5 August 2015 / Revised: 24 September 2015 / Accepted: 29 September 2015 / Published online: 6 October 2015

(C) The Author(s) 2015. This article is published with open access at Springerlink.com

\begin{abstract}
GPS collar-recorded temperature is often considered as a proxy for the ambient temperature in wildlife ecology studies, yet few studies actually test its reliability as well as the correlation with ambient temperature. Here, we address this question and demonstrate a strong correlation between collar temperature and weather station data, indicating that GPS collar sensor data can be regarded as a reliable index of ambient air temperature. Using data obtained from 384 free-ranging moose equipped with GPS collars between latitude $57^{\circ} \mathrm{N}$ to $68^{\circ} \mathrm{N}$ in Sweden, we analyzed $1,467,361$ paired observations of collar temperature and air temperature of the nearest official Swedish Meteorological and Hydrological Institute station. We found a systematic offset that varied across months, being larger during the warm summer months than during the winter period. We found an average correlation of $.91\left(r_{\mathrm{s}}\right.$; range .75 to .93 , median .91) between collar and ambient temperature of the nearest weather station. Thus, temperature sensors in, e.g., a GPS collar, may be used to study animal behavior, movement and habitat choice in relation to ambient air temperature. This aligns with the calls for using animals as not only subjects but also as the samplers of the environment. It also opens up possibilities for largescale projects on animal ecology and physiology in the absence of ground measuring stations on higher spatial scales like home range and landscape. As an application of collar temperature, we show that changes in the movement patterns seem to be highly
\end{abstract}

Göran Ericsson

Goran.Ericsson@slu.se

1 Department of Wildlife, Fish and Environmental Studies, Swedish University of Agricultural Sciences (SLU), SE-901 83 Umeå, Sweden

2 Department of Forestry and Wildlife Management, Faculty of Applied Ecology and Agricultural Sciences, Hedmark University College, Campus Evenstad, NO-2418 Elverum, Norway influenced by temperature-induced heat stress that moose experience during summer.

Keywords Climate $\cdot$ Collar $\cdot$ Sensor $\cdot$ Large mammals . Temperature

\section{Introduction}

Today most GPS-tracking units used in wildlife research are equipped with temperature sensors as a standard device (Wilmers et al. 2015). This enables coupling of exact GPS position data in three dimensions (longitude, latitude, altitude) with temperature data. It has opened up a wide array of possibilities for ecologists worldwide. However, a key challenge for the growing number of studies analyzing relationships between temperature, animal behavior, and general ecology is how accurately does the built-in temperature sensor monitor the air temperature at the location of the animal (Whiteman et al. 2015)? For species with restricted movements, fixed ground temperature loggers are the natural option both from a logistic and economic standpoint (Herr et al. 2009). For animals which roam over large areas, the option with ground temperature loggers is not feasible. Long distance movers such as wolf (Canis lupus), bear (Ursus sp.), and migratory ungulates such as moose (Alces alces), wildebeest (Connochaetes sp.), zebras (Equus sp.), and saiga antelope (Saiga tatarica), are examples of species today that have simultaneous recording of GPS and temperature data (Singh et al. 2012; Wilmers et al. 2015).

Published studies often tend to use the recorded collar temperature without correction, or knowing, if the offset between true air (ambient) temperature is systematic or random in time or space (e.g., Street et al. 2015). In the absence of correction factors or true independent ambient temperature measurements, other techniques like protected covers have been applied to reduce, e.g., the impact of radiation (e.g., Marchand et al. 
2015). In order to improve the information content from paired positional and temperature data, knowledge of the offset between true ambient temperature and the readings supplied by the tracking units are needed. In this note, we make use of a large data set on moose from 2003 to 2010 (WRAM: Dettki et al. 2013) to test the strength of correlation between collar temperature and ambient air temperature across the Swedish latitudinal gradient during the year.

\section{Material and methods}

\section{Data collection}

Within a set of thematic programs and projects, we have access to study moose populations from latitude $56 \mathrm{~N}$ to 68 N (for detailed description see Singh et al. 2012). The data set used consists of 384 moose marked with GPS collars and tracked across Sweden from latitude $57 \mathrm{~N}$ to $68 \mathrm{~N}$. The time period of tracking ranges from 2003 to 2010, with individual moose tracked for up to 5 years. Animals were chemically immobilized and equipped with a GPS/GSM neck collar (Vectronic Aerospace GmbH, Berlin, Germany) during winter. The data was automatically entered into the wireless remote animal monitoring database system for data validation and management (Dettki et al. 2013). Positions and temperature were usually logged every .5 to $3 \mathrm{~h}$. All temperature data were downloaded freely from the Swedish Meteorological and Hydrological Institute (SMHI; www.shi.se).

\section{Data analysis}

For each single moose position and related collar temperature, we matched it with temperature data from SMHI's nearest weather station (www.smhi.se). For each paired observation, we calculated the offset in ${ }^{\circ} \mathrm{C}$ and then an average offset per day, per month, and by latitude. Given the dense network of active weather stations during our study period in our study area, the distance between the moose collar temperature and each station reading was matched against and varied between .04 and $99.9 \mathrm{~km}$ (mean=31.4 km, SD=18.7 km). According to SMHI's spatial autocorrelation analysis for temperature, the autocorrelation in the kilometer range is 95-100\% (Alexandersson 2002). The data analysis was conducted using SAS software (SAS Institute Inc., Cary, NC, USA).

\section{Results and discussion}

On average, we found a correlation of $.91\left(r_{\mathrm{s}}\right.$; range .75 to .93 , median .91, $p<.0001$ ) between collar and ambient temperature of the nearest weather station. The offset was on average $7.2{ }^{\circ} \mathrm{C}$ and varied along the north-south gradient between 6.6 and $8.0{ }^{\circ} \mathrm{C}$ on an annual basis (Table 1). An interesting observation is that in winter, the offset was around $6{ }^{\circ} \mathrm{C}$ for animals living around and above (latitude $\left.65^{\circ} \mathrm{N}-68^{\circ} \mathrm{N}\right)$ the Arctic Circle ( $66^{\circ} 33^{\prime} 45.8^{\prime \prime} \mathrm{N}$, i.e., limited hours or no daylight in winter) which indicates that moose fur, placement, and insulation give an offset of $6{ }^{\circ} \mathrm{C}$

Table 1 Average offset in ${ }^{\circ} \mathrm{C}$ ( $n$-paired observations) by latitude (Lat) between moose collar ambient temperature sensor and temperature reading at the nearest official Swedish Meteorological and Hydrological Institute station

\begin{tabular}{|c|c|c|c|c|c|c|c|c|c|c|c|c|c|}
\hline & Average & Jan & Feb & Mar & Apr & May & June & July & Aug & Sept & Oct & Nov & Dec \\
\hline & $\begin{array}{l}7.2 \\
(1,467,361)\end{array}$ & 6.1 & 6.3 & 6.7 & 7.0 & 7.8 & 9.5 & 9.8 & 8.5 & 7.1 & 6.1 & 5.6 & 6.1 \\
\hline Lat $68^{\circ} \mathrm{N}$ & $\begin{array}{l}6.8 \\
(96,665)\end{array}$ & 5.7 & 6.3 & 5.8 & 6.7 & 7.6 & 9.4 & 10.5 & 9.2 & 6.7 & 4.6 & 4.1 & 4.6 \\
\hline Lat $67^{\circ} \mathrm{N}$ & $\begin{array}{l}7.4 \\
(103,906)\end{array}$ & 7.5 & 7.4 & 6.8 & 7.3 & 7.8 & 9.2 & 9.8 & 8.5 & 6.6 & 5.8 & 5.7 & 6.8 \\
\hline Lat $66^{\circ} \mathrm{N}$ & $\begin{array}{l}7.1 \\
(584,277)\end{array}$ & 5.6 & 5.9 & 6.4 & 6.6 & 7.3 & 9.6 & 10.5 & 9.0 & 7.4 & 5.9 & 5.3 & 5.7 \\
\hline Lat $65^{\circ} \mathrm{N}$ & $\begin{array}{l}8.0 \\
(333,477)\end{array}$ & 6.3 & 6.7 & 7.2 & 7.6 & 8.2 & 10.2 & 11.3 & 10.1 & 8.6 & 7.0 & 6.3 & 6.5 \\
\hline Lat $64^{\circ} \mathrm{N}$ & $\begin{array}{l}6.7 \\
(103,447)\end{array}$ & 5.6 & 6.2 & 6.7 & 6.4 & 6.4 & 8.7 & 9.1 & 7.3 & 6.3 & 5.6 & 6.3 & 6.3 \\
\hline Lat $59^{\circ} \mathrm{N}$ & $\begin{array}{l}7.2 \\
(68,198)\end{array}$ & 6.5 & 7.5 & 7.2 & 7.8 & 8.4 & 9.2 & 7.3 & 5.7 & 5.8 & 6.8 & 6.3 & 7.2 \\
\hline Lat $58^{\circ} \mathrm{N}^{\mathrm{a}}$ & $\begin{array}{l}6.6 \\
(7497)\end{array}$ & 6.8 & 4.8 & 6.7 & 7.3 & 8.3 & 9.2 & 7.0 & 6.6 & 5.8 & 5.2 & 4.8 & * \\
\hline Lat $57^{\circ} \mathrm{N}$ & $\begin{array}{l}7.1 \\
(169,894)\end{array}$ & 7.4 & 6.7 & 7.3 & 7.3 & 8.7 & 9.2 & 6.8 & 6.2 & 6.1 & 6.6 & 5.8 & 7.7 \\
\hline
\end{tabular}

${ }^{a}$ Only 11 months of data from 1 year 


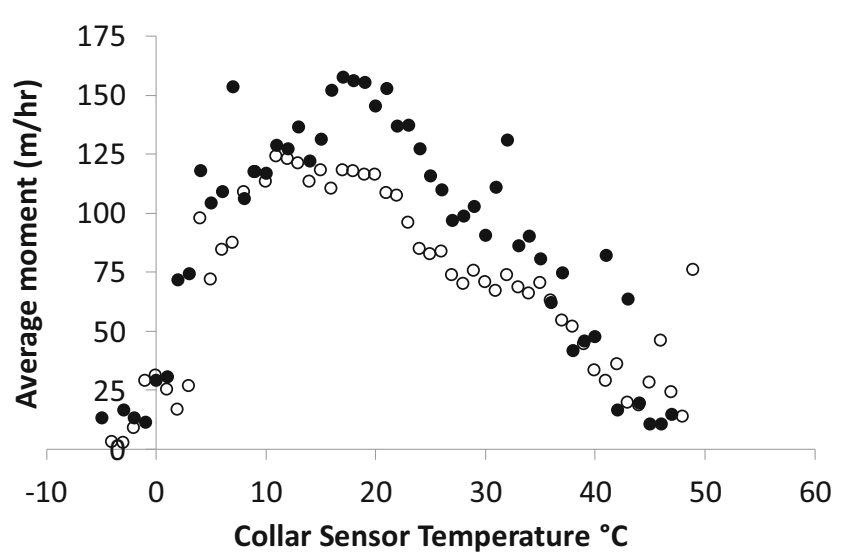

Fig. 1 Example of potential application using collar temperature sensor data when offset is known. Data from latitude 66 N, June and July 2005/ 2006. Filled circles male $(n=8)$, open circles female moose $(n=27)$

in the absence of incoming radiation. The largest offsets are recorded during the summer months, particularly from the more northern populations with long days and for some populations during midnight sun (latitude $66^{\circ} \mathrm{N}$ to $68^{\circ} \mathrm{N}$ ).

Our methodological study across the latitudinal range of Sweden supports the premise that a GPS collar's temperature sensor monitors ambient temperature with a systematic offset and with a strong correlation to true air temperature. Our results lend support to the studies of movement, habitat choice, and migration of higher spatial orders such as the home range and landscape scale which can use collar-mounted temperature sensors. Given that the offset is systematic, it opens up possibilities for conducting studies in remote areas where temperature-related issues are pivotal. The limitation may occur when individual behavior in relation to physiology is the core research question.

\section{Potential application}

In locations, like in Sweden, where it is possible to verify the offset using the dense grid of official meteorological stations, some physiological aspects like heat stress may be possible to study without the need for bio-loggers. In a classical paper, Renecker and Hudson (1986) established temperature thresholds when heat stress affected moose physiology, using penned moose. They showed that respiration rate increased above $14{ }^{\circ} \mathrm{C}$ and that open-mouthed panting began at $20^{\circ} \mathrm{C}$. Energy expenditure and heart rate followed a similar rise with increasing ambient temperature. Thus, putting our finding into an application for wildlife researchers, we can use collar temperature to study if heat stress affects movement. As a worked example, we test if we can detect any effect of heat stress on moose movement during JuneJuly $2005 / 2006$ at latitude $66^{\circ} \mathrm{N}$ when the established offset is circa $10{ }^{\circ} \mathrm{C}$ (Table 1 ; subset of data $\left(n_{\text {females }}=\right.$ $27, n_{\text {males }}=8$ individuals; $n_{\text {females }}=79,597 ; n_{\text {males }}=18,599$ paired observations of movement and temperature). It is clear from Fig. 1 that both sexes are most active (highest average movement $\mathrm{m} / \mathrm{h}$ ) around a collar temp of $17{ }^{\circ} \mathrm{C}$ which translates into $7{ }^{\circ} \mathrm{C}$ ambient temperature. Following Renecker and Hudson (1986) findings, moose of both sexes decreased their activity at a collar temperature of around $24{ }^{\circ} \mathrm{C}\left(14{ }^{\circ} \mathrm{C}\right.$ ambient $)$ and at a collar temperature above $30{ }^{\circ} \mathrm{C}\left(20{ }^{\circ} \mathrm{C}\right.$ ambient $)$; they substantially reduced movement. Overall, at a given temperature, Fig. 1 suggests that males were moving a faster speed. In conclusion, we suggest that changes in the movement patterns seem to be highly related to the temperature-induced heat stress moose might be experiencing during summer.

Acknowledgments We acknowledge the Swedish EPA for the funding, the Swedish Polar Institute and the International Polar Year, the Kempe foundation, the programs Beyond Moose and Wildlife and Forestry, the EU/Interreg program Moose in Midscandinavia, the Swedish Association for Hunting and Wildlife management, the Swedish University of Agricultural Sciences (SLU), the county boards of Västerbotten and Norrbotten for the funding and various form of support from 2003 and on.

Compliance with ethical standards The projects included were approved by the Animal Care Committees in Umeå and Linköping and was carried out in accordance with Swedish laws concerning animal research ethics. All personnel were certified according to the standards by SLU, the Swedish Animal Welfare Agency and the Swedish Board of Agriculture.

Open Access This article is distributed under the terms of the Creative Commons Attribution 4.0 International License (http:// creativecommons.org/licenses/by/4.0/), which permits unrestricted use, distribution, and reproduction in any medium, provided you give appropriate credit to the original author(s) and the source, provide a link to the Creative Commons license, and indicate if changes were made.

\section{References}

Alexandersson H (2002) Temperatur och nederbörd i Sverige 18602001, Meteorologi Nr 104, SMHI, ISNN 0283-7730

Dettki H, Ericsson G, Giles T, Norrsken-Ericsson, M (2013) Wireless Remote Animal Monitoring (WRAM) - A new international database e-infrastructure for telemetry sensor data from fish and wildlife. In: Proceedings Etc. 2012: Convention for Telemetry, Test Instrumentation and Telecontrol (Eds. The European Society of Telemetry), pp. 247-256., ISBN: 978-3-7322-5646-4

Herr J, Schley L, Roper TJ (2009) Stone martens (Martes foina) and cars: investigation of a common human-wildlife conflict. Eur J Wildl Res 55:471-477. doi:10.1007/s10344-009-0263-6

Marchand P, Garel M, Bourgoin G, Dubray D, Maillard D, Loison A (2015) Sex-specific adjustments in habitat selection contribute to buffer mouflon against summer conditions. Behav Ecol 26:472-482

Renecker LA, Hudson RJ (1986) Seasonal energy expenditures and thermoregulatory responses of moose. Can J Zool 64:322-327

Singh NJ, Börger L, Dettki H, Bunnefeld N, Ericsson G (2012) From migration to nomadism: movement variability in a northern ungulate across its latitudinal range. Ecol Appl 22:2007-2020 
Street GM, Rodgers AR, Fryxell JM (2015) Mid-day temperature variation influences seasonal habitat selection by moose. J Wildl Man 79:505-512

Whiteman JP, Harlow HJ, Durner GM, Anderson-Sprecher R, Albeke SE, Regehr EV, Amstrup SC, Ben-David M (2015) Summer declines in activity and body temperature offer polar bears limited energy savings. Science 349:295-298

Wilmers CC, Nickel B, Bryce CM, Smith JA, Wheat RE, Yovovich V (2015) The golden age of bio-logging: how animal-borne sensors are advancing the frontiers of ecology. Ecology 96:1741-1753 